\title{
Early reperfusion therapy improves left ventricular function after acute inferior myocardial infarction associated with right coronary artery disease
}

\begin{abstract}
Quantitative global and regional ventriculographic analysis was performed acutely and 1 week later in 46 patients undergoing reperfusion procedures within 6 hours of acute inferior myocardlal infarction due to right coronary artery disease. While serial improvement in global left ventricular ejection fraction was not demonstrated for the group, Infarct zone regional wall motion did improve $(-2.7 \pm 0.9$ vs $-2.3 \pm 1.4 \mathrm{SD} /$ chord, $p<0.007)$. Serial improvement in giobal ejection fraction was demonstrated in the subgroup of patients treated within 2 hours of symptom onset ( $55 \pm 10$ v8 $62 \pm 10 \% ; n=5 ; p<0.03$ ). Infarct zone reglonal wall motion improved serially only in the subgroup of patients treated within 3 hours of symptom onset $(-2.4 \pm 1.1$ vs $-1.3 \pm 1.7 \mathrm{SD} /$ chord; $n=11 ; p<0.007)$. Patients with initially patent arteries had a higher ejection fraction on follow-up catheterization than did those with initlally occluded vessels $(61 \pm 11$ v8 $55 \pm 7 \% ; p<0.02)$, and patients with patent arteries at follow-up had a higher ejection fraction than did those whose arteries were occluded (60 \pm 9 vs $48 \pm 4 \%$; $p<0.0001$ ). We conclude that significant improvement in global and regional left ventricular function in patients with inferior myocardial infarction is possible when reperfusion therapy is begun early or when arterial patency is achieved. (Am HeART J 1987;114:261.)
\end{abstract}

Eric R. Bates, M.D., Eric J. Topol, M.D., Eva M. Kline, B.S.N., Alan B. Langburd, M.D., Anthony Y. Fung, M.D., Joseph A. Walton, Jr., M.D., Patrick D.V. Bourdillon, M.D., Robert A. Vogel, M.D., Bertram Pitt, M.D., and William W. O’Neill, M.D. Ann Arbor, Mich.

Prognosis following inferior myocardial infarction is significantly better than prognosis following anterior myocardial infarction..$^{1-3}$ Inferior infarction is associated with a smaller enzyme release $e^{1-3}$ and a higher left ventricular ejection fraction, ${ }^{4,5}$ suggesting that less myocardial damage occurs. This is reflected clinically by a lower incidence of congestive heart failure ${ }^{2-4}$ and death. ${ }^{1-3} \mathrm{~A}$ major goal of reperfusion therapy is to preserve left ventricular function by reperfusing ischemic myocardium. It has been suggested $^{6,7}$ that improvement in ventricular function is inversely proportional to the extent of initial dys-

From the Division of Cardiology, Department of Internal Medicine, University of Michigan, Ann Arbor.

Received for publication Nov. 7, 1986; accepted March 10, 1987.

Reprint requests: Eric R. Bates, M.D., Division of Cardiology, Veteran's Administration Medical Center, 2215 Fuller Rd., Ann Arbor, MI 48105. function. Since global left ventricular function $m \imath y$ be relatively normal following inferior infarction,, .5 the extent of myocardial salvage to be expected fro $n$ reperfusion therapy in these patients may not justi: $y$ the risk and expense.

The purpose of this study was to determine the effect of acute reperfusion therapy on global ard regional left ventricular function in patients wilh acute inferior myocardial infarction due to riglit coronary artery disease who were treated within 6 hours of symptom onset. Patients with circumfle $X$ coronary artery disease constitute a small minority of patients with inferior infarction undergoirg reperfusion therapy and were excluded from this study because myocardial salvage cannot be adequately assessed from single-plane 30 -degree right anterior oblique ventriculograms. ${ }^{8}$ 
Table I. Coronary arteriographic results by treatment group

\begin{tabular}{lccccc}
\hline & $\begin{array}{c}\text { PTCA } \\
(n=19)\end{array}$ & $\begin{array}{c}\text { SK/PTCA } \\
(n=10)\end{array}$ & $\begin{array}{c}t-P A \\
(n=11)\end{array}$ & $\begin{array}{c}t-P A / P T C A \\
(n=6)\end{array}$ & $\begin{array}{c}\text { Total } \\
(n=46)\end{array}$ \\
\hline Age & $57 \pm 10$ & $54 \pm 12$ & $55 \pm 8$ & $50 \pm 11$ & $52 \pm 10$ \\
Initial arterial patency & $3(16 \%)$ & $6(60 \%)$ & $6(55 \%)$ & $3(50 \%)$ & $18(39 \%)$ \\
Final arterial patency & $18(95 \%)$ & $10(100 \%)$ & $11(100 \%)$ & $5(83 \%)$ & $44(96 \%)$ \\
Follow-up arterial patency & $15(79 \%)$ & $9(90 \%)$ & $8(73 \%)$ & $4(67 \%)$ & $36(78 \%)$ \\
Initial arterial \% stenosis & $99 \pm 2$ & $92 \pm 10$ & $85 \pm 19$ & $97 \pm 4$ & $94 \pm 11$ \\
Final arterial \% stenosis & $46 \pm 21$ & $35 \pm 10$ & $79 \pm 16$ & $36 \pm 29$ & $50 \pm 26$ \\
Follow-up arterial \% stenosis & $52 \pm 30$ & $41 \pm 24$ & $71 \pm 29$ & $58 \pm 31$ & $55 \pm 30$ \\
\hline
\end{tabular}

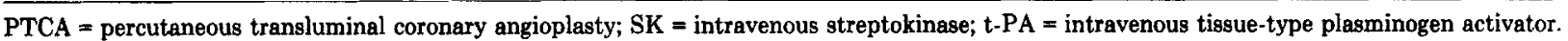

\section{METHODS}

Patient selection. From May, 1984, to February, 1986, 148 patients with acute myocardial infarction by enzymatic criteria were prospectively enrolled in reperfusion therapy protocols at the University of Michigan Medical Center. All underwent cardiac catheterization both acutely and 7 to 10 days later. Inclusion criteria were: (1) chest pain of greater than 20 minutes' duration, but of less than 6 hours' duration, consistent with ischemia and unrelieved by sublingual nitroglycerin; (2) at least $1 \mathrm{~mm}$ ST segment elevation in two contiguous ECG leads; (3) age less than 75 years. Exclusion criteria for this study were: (1) recent history of trauma, surgery, stroke, bleeding or prolonged cardiopulmonary resuscitation: (2) previous coronary bypass surgery or transmural infarction; (3) cardiogenic shock. The right coronary artery was identified as the infarct-related artery in 64 patients. Eighteen patients were subsequently excluded for the following reasons. Follow-up catheterization was not performed in three patients who died shortly after reperfusion therapy, in three patients who refused the follow-up study, and in three patients who underwent immediate coronary bypass surgery because of severe triple-vessel disease. Two patients were excluded because of previous myocardial infarction, while seven others had ventriculograms that were inadequate for analysis. Thus, 46 patients had acute and follow-up contrast ventriculograms suitable for quantitative analysis and they constitute the study group. Nineteen were treated with percutaneous transluminal coronary angioplasty alone, 10 were treated with intravenous streptokinase followed by immediate angioplasty, 11 were treated with intravenous tissue-type plasminogen activator alone, and six were treated with tissue-type plasminogen activator followed by immediate angioplasty. These protocols were approved by the University of Michigan Institutional Review Board. Informed consent was obtained from each patient.

\section{Interventional protocols}

1. Intravenous lytic therapy. Patients receiving streptokinase were premedicated with intravenous hydrocortisone, $200 \mathrm{mg}$, and were then given a total of 1.5 million $U$ of streptokinase over 30 minutes, following a test dose. Patients receiving tissue-type plasminogen activator were given $0.75 \mathrm{mg} / \mathrm{kg}$ over 1 hour and $0.5 \mathrm{mg} / \mathrm{kg}$ over the subsequent 2 hours, for a total dose of $1.25 \mathrm{mg} / \mathrm{kg}$ over 3 hours. The recombinant tissue-type plasminogen activator was predominately a single-chain preparation (Genentech, San Francisco, Calif.)

2. Angiography. Vascular sheaths were placed in a femoral artery and vein and $5000 \mathrm{U}$ of intravenous heparin was administered. By means of the Judkins technique, selective coronary arteriography was performed in multiple projections and then ventriculography was performed in the 30-degree right anterior oblique projection.

3. Angioplasty. Patients receiving angioplasty were given an additional $5000 \mathrm{U}$ of intravenous heparin. The procedure was performed only in the infarct vessel with a steerable guidewire and balloon catheter system.

4. Hospital course. Therapeutic heparin infusion was continued until repeat angiography was performed 7 to 10 days later, except for a few hours on the second hospital day when the vascular sheaths were removed. Patients were also treated with aspirin, $325 \mathrm{mg}$ one to three times per day, dipyridamole, $75 \mathrm{mg}$ three times per day, and diltiazem, $30 \mathrm{mg}$ four times per day.

Analysis of left ventricular function. To measure left ventricular function, end-diastolic and end-systolic outlines were independently projected and traced by two blinded experienced angiographers from a non-postpremature normal sinus beat. Global ejection fraction was determined by means of the area-length method. ${ }^{y}$ When results obtained by the two determinations differed by more than $5 \%$, a joint determination of outlines was performed. Regional wall motion was determined by the centerline method..$^{10,11}$ Briefly, 100 equally spaced chords are constructed perpendicular to a centerline drawn midway between the end-diastolic and end-systolic outlines. Motion along the perpendicular lines is normalized for centerline length and is expressed in units of standard deviation of mean wall motion obtained from ventriculographic analysis of 64 normal subjects. ${ }^{10}$ Regional wall motion is calculated as the mean motion of chords lying in the most hypokinetic $50 \%$ of the infarct zone or the most hyperkinetic $50 \%$ of the non-infarct zone, and is expressed in standard deviations per chord. Negative and positive values are respectively hypokinetic and hyperkinetic compared with normal mean wall motion.

Statistical analysis. Results are expressed as mean \pm 


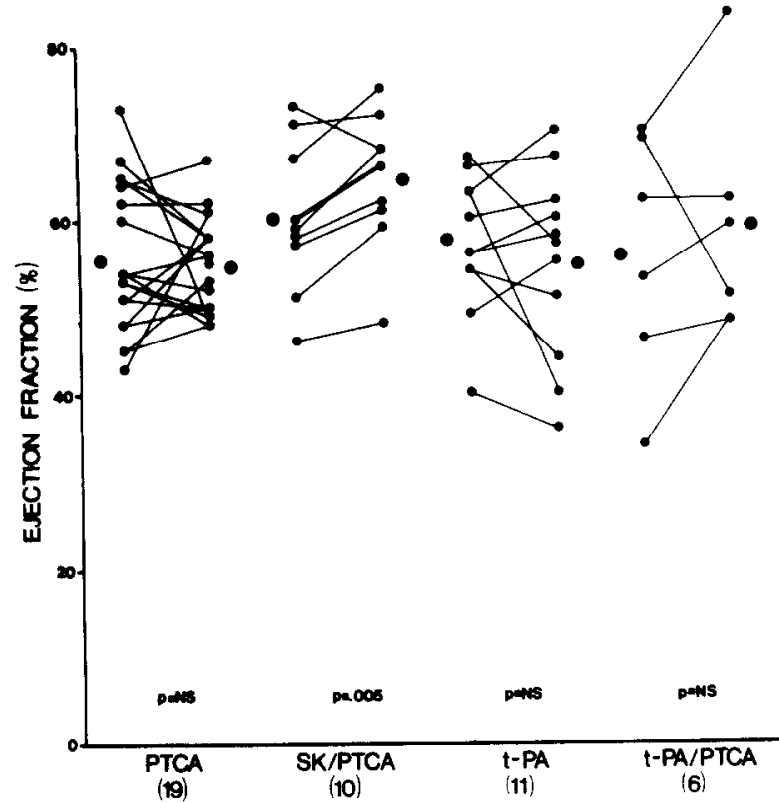

Fig. 1. Change in ejection fraction in acute and followup studies in each patient group. $P T C A=$ percutaneous transluminal coronary angioplasty; $S K=$ intravenous streptokinase; $t$ - $P A=$ intravenous tissue-type plasminogen activator.

SD. Paired $t$ tests were performed to compare initial and follow-up values. Unpaired $t$ tests were used for intergroup comparisons. A probability $(p)$ value of less than 0.05 was considered statistically significant.

\section{RESULTS}

Coronary arteriography (Table I). The initial arteriogram revealed right coronary artery patency with good visualization of the distal vessel in 18 of 46 (39\%) patients. Those studied after intravenous lytic therapy had a higher initial patency rate than those who had not received lytic therapy (15 of 27 vs 3 of $19, p<0.007)$. The last arteriogram following completion of reperfusion therapy demonstrated arterial patency in 44 of $46(96 \%)$ patients. Patency 1 week later was demonstrated in 36 of $46(78 \%)$ patients.

Arterial percent stenosis of the infarct-related artery was significantly less following reperfusion therapy in patients treated with angioplasty compared to patients treated only with lytic therapy $(41 \pm 21$ vs $79 \pm 16, p<0.03)$. Arterial percent stenosis 1 week later increased slightly in each group due to inclusion of patients with arterial reocclusion.

Ventricular function by treatment group (Figs. 1 and 2, Table II). No significant serial improvement in ejection fraction between the initial and follow-up studies was found for the total group. However,

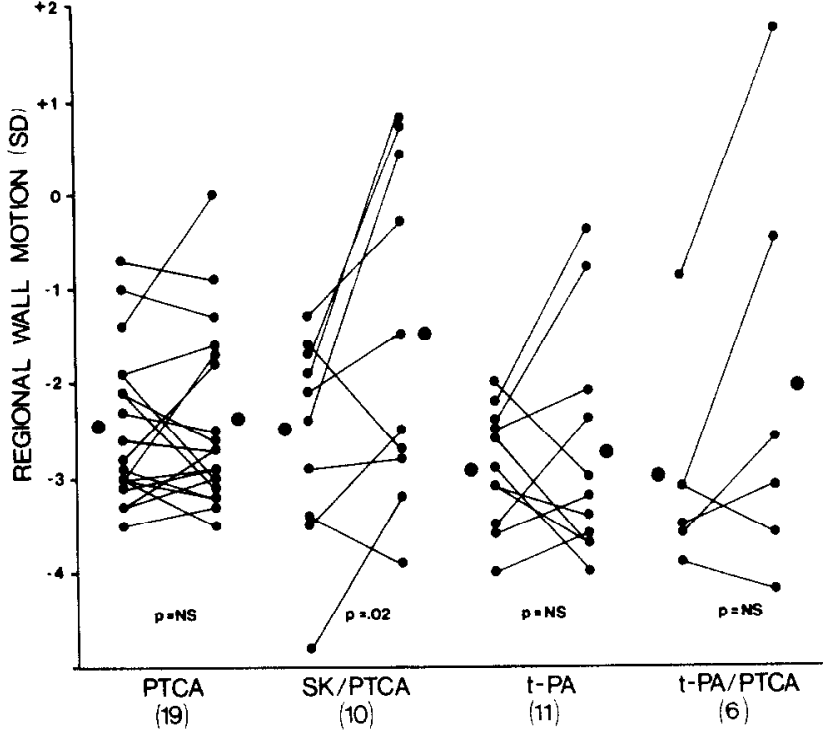

Fig. 2. Change in regional wall motion in the infarct zone in acute and follow-up studies in each patient group. Abbreviations as in Fig. 1.

patients treated with streptokinase plus angioplasty did experience an improvement in ejection fraction $(60 \pm 8 \%$ vs $65 \pm 7 \%, p<0.005)$. Importantly, time to treatment in this group was at least 93 minutes sooner than treatment in the other groups.

Regional wall motion in the infarct zone improved significantly only in the streptokinase plus angioplasty group $(-2.6 \pm 1.0$ vs $-1.5 \pm 1.7 \mathrm{SD} /$ chord, $p<0.02)$ and in the total group $(-2.7 \pm 0.9$ vs $-2.3 \pm 1.4 \mathrm{SD} /$ chord, $p<0.007)$. Regional wall motion in the non-infarct zone did not change in any group.

Ventricular function by time to treatment (Table III). Patients treated less than 2 hours from symptom onset had serial improvement in ejection fraction $(55 \pm 10$ vs $62 \pm 10 \%, p<0.03)$, while those treated after 2 hours did not. Improvement in infarct zone regional wall motion was found only in patients treated within 3 hours of symptom onset $(-2.4 \pm 1.1$ vs $-1.3 \pm 1.7 \mathrm{SD} /$ chord, $p<0.007)$.

Ventricular function by patency status (Table IV). Neither initial nor follow-up arterial patency were associated with serial improvement in ejection fraction. On follow-up catheterization, however, patients with initially patent arteries had a higher ejection fraction than did those with initially occluded arteries $(61 \pm 11$ vs $55 \pm 7 \%, p<0.02)$, and patients with persistently patent arteries had a higher ejection fraction than did those whose arteries were occluded ( $60 \pm 9$ vs $48 \pm 4 \%, p<0.0001)$.

Serial improvement in infarct zone regional wall 
Table II. Global and regional left ventricular function by treatment group

\begin{tabular}{|c|c|c|c|c|c|}
\hline & $\begin{array}{c}\text { PTCA } \\
(n=19)\end{array}$ & $\begin{array}{c}S K / P T C A \\
(n=10)\end{array}$ & $\begin{array}{c}t-P A \\
(n=11)\end{array}$ & $\begin{array}{c}t-P A / P T C A \\
(n=6)\end{array}$ & $\begin{array}{c}\text { Total } \\
(n=46)\end{array}$ \\
\hline \multicolumn{6}{|l|}{ Ejection fraction (\%) } \\
\hline Acute & $55 \pm 8$ & $60 \pm 8$ & $57 \pm 8$ & $56 \pm 13$ & $57 \pm 9$ \\
\hline Follow-up & $55 \pm 5$ & $65 \pm 7$ & $55 \pm 10$ & $59 \pm 12$ & $57 \pm 9$ \\
\hline Delta & $-0.5 \pm 8$ & $4.5 \pm 4$ & $-2.5 \pm 8$ & $3 \pm 11$ & $0.5 \pm 8$ \\
\hline$p$ Value & NS & 0.005 & NS & NS & NS \\
\hline \multicolumn{6}{|c|}{ Regional wall motion (SD/chord) infarct zone } \\
\hline Acute & $-2.5 \pm 0.8$ & $-2.6 \pm 1.0$ & $-2.9 \pm 0.6$ & $-3.0 \pm 1.0$ & $-2.7 \pm 0.9$ \\
\hline Follow-up & $-2.4 \pm 0.9$ & $-1.5 \pm 1.7$ & $-2.8 \pm 1.1$ & $-2.1 \pm 2.0$ & $-2.3 \pm 1.4$ \\
\hline Delta & $0.1 \pm 0.7$ & $1.1 \pm 1.3$ & $0.1 \pm 1.0$ & $1.0 \pm 1.2$ & $0.4 \pm 1.1$ \\
\hline$p$ Value & NS & 0.02 & NS & NS & 0.007 \\
\hline \multicolumn{6}{|c|}{ Regional wall motion (SD/chord) non-infarct zone } \\
\hline Acute & $1.1 \pm 1.4$ & $1.9 \pm 1.1$ & $0.3 \pm 1.6$ & $0.1 \pm 1.3$ & $1.0 \pm 1.5$ \\
\hline Follow-up & $0.8 \pm 1.1$ & $1.8 \pm 1.1$ & $0.2 \pm 1.4$ & $0.4 \pm 1.6$ & $0.8 \pm 1.4$ \\
\hline Delta & $-0.4 \pm 1.3$ & $-0.1 \pm 0.4$ & $-0.1 \pm 1.2$ & $0.2 \pm 1.0$ & $-0.2 \pm 1.1$ \\
\hline$p$ Value & NS & NS & NS & NS & NS \\
\hline Time to treatment (min) & $254 \pm 59$ & $135 \pm 68$ & $228 \pm 44$ & $257 \pm 44$ & $222 \pm 74$ \\
\hline
\end{tabular}

Delta $=$ difference between acute and follow-up values; NS $=$ not significant; other abbreviations as in Table $\mathrm{I}$.

Table III. Global and regional left ventricular function by time to treatment

\begin{tabular}{|c|c|c|c|}
\hline & $<2 h r(n=5)$ & $<3 h r(n=11)$ & $\geq 3 h r(n=35)$ \\
\hline \multicolumn{4}{|c|}{ Ejection fraction $(\%)$} \\
\hline Acute & $55 \pm 10$ & $59 \pm 10$ & $56 \pm 9$ \\
\hline Follow-up & $62 \pm 10$ & $63 \pm 9$ & $56 \pm 9$ \\
\hline Delta & $7.5 \pm 6$ & $3.5 \pm 7$ & $-0.5 \pm 9$ \\
\hline$p$ Value & 0.08 & NS & NS \\
\hline \multicolumn{4}{|c|}{ Regional wall motion (SD/chord) infarct zone } \\
\hline Acute & $-2.0 \pm 0.6$ & $-2.4 \pm 1.1$ & $-2.7 \pm 0.8$ \\
\hline Follow-up & $-0.2 \pm 1.5$ & $-1.3 \pm 1.7$ & $-2.5 \pm 1.2$ \\
\hline Delta & $1.9 \pm 1.1$ & $1.1 \pm 1.2$ & $-0.2 \pm 1.0$ \\
\hline$p$ Value & 0.01 & 0.007 & NS \\
\hline \multicolumn{4}{|c|}{ Regional wall motion (SD/chord) non-infarct zone } \\
\hline Acute & $1.3 \pm 0.9$ & $1.4 \pm 1.5$ & $0.8 \pm 1.5$ \\
\hline Follow-up & $0.8 \pm 1.1$ & $1.4 \pm 1.5$ & $0.6 \pm 1.3$ \\
\hline Delta & $-0.5 \pm 0.5$ & 0 & $0.2 \pm 1.2$ \\
\hline$p$ Value & NS & NS & NS \\
\hline
\end{tabular}

Abbreviations as in Table II.

motion occurred in patients with both initially patent $\quad(-2.2 \pm 0.9$ vs $-1.3 \pm 1.7 \mathrm{SD} /$ chord, $p<0.006)$ and persistently patent arteries $(-2.6 \pm$ 0.9 vs $-2.0 \pm 1.5 \mathrm{SD} /$ chord, $p<0.003$ ). No improvement occurred in patients with initially occluded or persistently occluded arteries. Patients with initially patent arteries had better infarct zone regional wall motion than did those with initially occluded arteries, both initially $(-2.2 \pm 0.9$ vs $-3.0 \pm 0.8 \mathrm{SD} /$ chord, $p<0.002)$ and at follow-up $(-1.3 \pm 1.7 \mathrm{vs}$ $-2.9 \pm 0.8$ SD/chord, $p<0.0001$ ). Patients with persistently patent arteries had better infarct zone regional wall motion than did those with persistently occluded arteries at follow-up $(-2.0 \pm 1.5$ vs $-3.1 \pm 0.4 \mathrm{SD} /$ chord, $p<0.01$ ).

\section{DISCUSSION}

Global ejection fraction. Although the Western Washington randomized, controlled trial demonstrated no improvement in left ventricular ejection fraction when streptokinase therapy was given approximately 5 hours after symptom onset in acute myocardial infarction, ${ }^{12,13}$ a more recent trial by Serruys et al. ${ }^{14}$ with streptokinase administered within 3 hours of symptom onset in patients without previous infarction did show a significant improvement in ejection fraction compared to the control group, both in patients with inferior infarction and anterior infarction.

More controversial is whether streptokinase therapy results in further improvement in ejection fraction on serial testing following the acute ejection fraction determination. While analysis of patients with persistently patent arteries in uncontrolled studies have shown serial improvement in ejection fraction,,$^{15-18}$ patients analyzed by the intention-totreat principle ${ }^{14,19,20}$ have not. Additionally, studies that used the area length method of contrast ventriculographic analysis employed in this study ${ }^{11,21}$ have not shown serial improvement in ejection fraction. This discrepancy is not explained by the route of streptokinase administration or by time to treatment differences. No serial improvement in ejection fraction following inferior infarction has previously been demonstrated. . $^{14,22,23}$

A severe residual stenosis following thrombolysis has been shown ${ }^{7}$ to limit functional recovery. Restricted blood flow or rethrombosis and reinfarction may explain why serial improvement in ejection fraction is not consistently found after lytic thera- 
Table IV. Global and regional left ventricular function by patency status

\begin{tabular}{|c|c|c|c|c|c|c|}
\hline & \multicolumn{3}{|c|}{ Initial status } & \multicolumn{3}{|c|}{ Follow-up status } \\
\hline & Patent $(n=18)$ & Occluded $(n=28)$ & p Value & Patent $(n=36)$ & Occluded $(n=10)$ & p Value \\
\hline \multicolumn{7}{|c|}{ Ejection fraction $(\%)$} \\
\hline Acute & $59 \pm 10$ & $56 \pm 8$ & NS & $59 \pm 9$ & $51 \pm 8$ & 0.008 \\
\hline Follow-up & $61 \pm 11$ & $55 \pm 7$ & 0.02 & $60 \pm 9$ & $48 \pm 4$ & 0.0001 \\
\hline Delta & $2 \pm 9$ & $-1 \pm 8$ & NS & $1 \pm 8$ & $-2.5 \pm 10$ & NS \\
\hline$p$ Value & NS & NS & & NS & NS & \\
\hline \multicolumn{7}{|c|}{ Regional wall motion (SD/chord) infarct zone } \\
\hline Acute & $-2.2 \pm 0.9$ & $-3.0 \pm 0.8$ & 0.002 & $-2.6 \pm 0.9$ & $-3.0 \pm 0.5$ & NS \\
\hline Follow-up & $-1.3 \pm 1.7$ & $-2.9 \pm 0.8$ & 0.0001 & $-2.0 \pm 1.5$ & $-3.1 \pm 0.4$ & 0.01 \\
\hline Delta & $0.9 \pm 1.4$ & $0.1 \pm 0.7$ & 0.005 & $0.6 \pm 1.2$ & $-0.1 \pm 6$ & 0.04 \\
\hline$p$ Value & 0.006 & NS & & 0.003 & NS & \\
\hline \multicolumn{7}{|c|}{ Regional wall motion (SD/chord) non-infarct zone } \\
\hline Acute & $0.8 \pm 1.7$ & $1.2 \pm 1.4$ & NS & $1.1 \pm 1.6$ & $0.5 \pm 1.3$ & NS \\
\hline Follow-up & $0.4 \pm 1.5$ & $1.1 \pm 1.3$ & NS & $0.9 \pm 1.5$ & $0.4 \pm 1.0$ & NS \\
\hline Delta & -0.3 & -0.1 & NS & $-0.2 \pm 1.2$ & $-0.2 \pm 0.8$ & NS \\
\hline$p$ Value & NS & NS & & NS & NS & \\
\hline
\end{tabular}

Abbreviations as in Table II.

py. ${ }^{7,24,25}$ Interestingly, preliminary evidence suggests that when angioplasty ${ }^{14,26,27}$ or coronary bypass surgery $^{28}$ follows lytic therapy, serial ejection fraction does improve. Our data also show that early lytic therapy followed by angioplasty can result in serial ejection fraction improvement in inferior infarction, while late treatment with lytic therapy and/or angioplasty does not. Regardless of whether or not serial improvement in ejection fraction occurs, it should be emphasized, both in our own and previous studies, that successful reperfusion with a documented patent vessel prior to hospital discharge results in a higher ejection fraction than is found with an occluded infarct-related artery.

Regional wall motion. As reported for ejection fraction, regional wall motion was not improved by reperfusion therapy in the Western Washington Study, in which streptokinase was given approximately 5 hours after symptom onset, ${ }^{12,13}$ while it was improved in the study by Serruys et al., ${ }^{14}$ in which streptokinase was administered within 3 hours of symptoms. All the nonrandomized studies that reported either presence or absence of serial improvement in ejection fraction following reperfusion therapy reported serial improvement in regional wall motion. ${ }^{15-21}$ Those that did not find serial improvement in ejection fraction found that compensatory hyperkinesia in the non-infarct zone often preserved initial ejection fraction despite severe hypokinesia in the infarct zone, thus masking potential global improvements. ${ }^{11,19,21}$ Serial improvement in infarct zone regional wall motion after inferior infarction has been reported for patients with patent $\operatorname{arteries}^{7,15,23}$ and for patients receiving streptoki- nase. ${ }^{14}$ Our data also show improvement in infarct zone regional wall motion, particularly in patients treated with streptokinase plus angioplasty. Time to treatment and patency staus were strong predictors of improvement.

Limitations. This study is limited by the fact that small groups of patients were treated by different interventions and that treatment was delayed in patients treated by angioplasty alone or by tissuetype plasminogen activator. These limitations reflect the rapid evolution of reperfusion therapy in our catheterization laboratory from direct angioplasty $^{20}$ to intravenous streptokinase followed by immediate angioplasty ${ }^{29}$ to intravenous tissue-type plasminogen activator with subsequent randomization to delayed angioplasty or immediate angioplasty. ${ }^{30}$ While patients treated with streptokinase received early therapy in their local emergency rooms, patients receiving direct angioplasty or tissue-type plasminogen activator had to be sent by ground or helicopter transport to our catheterization laboratory before treatment could be instituted, thus explaining the differences between groups in time to treatment. In spite of these limitations, improvement in ventricular function by reperfusion therapy in inferior infarction was demonstrated by this study. Earlier therapy would be expected to produce more dramatic improvement. 11, 15-17, 21, 22, 31

Not enough patients were treated with tissue-type plasminogen activator plus angioplasty to demonstrate a statistically significant improvement in ventricular function, although the serial changes obtained were similar to those in the streptokinase plus angioplasty group. Time to treatment was 2 
hours later, however, and was equivalent to patients treated only with either tissue-type plasminogen activator or with angioplasty who did not show improvement in ventricular function. More patients will have to be studied to determine if this form of sequential therapy provides a longer time frame within which reperfusion therapy can be applied with expectation of myocardial salvage.

Three patients died before the follow-up study could be obtained. All were clinically stable before reperfusion of a proximal arterial occlusion and then deteriorated rapidly, dying within 24 hours of hospitalization. This course of events has not occurred in our experience with reperfusion therapy in proximal left anterior coronary arteries. The hemodynamic sequelae of right ventricular infarction probably result from interruption of proximal right coronary artery blood flow to the crista supraventricularis. ${ }^{32}$ It is possible that the right ventricle is particularly susceptible to reperfusion injury ${ }^{33}$ and that this contributed to the demise of these patients.

Clinical implications. It is increasingly clear that reperfusion therapy in acute myocardial infarction has the potential to preserve left ventricular function $^{14-23,26-31}$ and decrease mortality. ${ }^{22,34}$ Data from this study and others demonstrate that myocardial salvage is critically dependent upon time to treatment and upon restoring arterial patency, and is not related to location of infarction. It is also probable that early angioplasty after lytic therapy is important in salvaging myocardium by preventing arterial reocclusion or by achieving acute arterial patency in arteries not reperfused by lytic therapy.

The effort and expense required to apply reperfusion therapy to all patients with acute infarction would require a major allocation of additional resources to the cardiac catheterization laboratory and regionalization of health care delivery. If treatment could be limited to subgroups of patients most likely to benefit from this form of therapy, the risk and expense could be reduced. Unfortunately, such subgroups have not yet been clearly defined. While therapy is better given earlier than later, intermittent coronary occlusion or the presence of collateral blood flow cannot be predicted noninvasively and extend the time frame within which myocardial salvage can be achieved. Although it has been suggested that ECG criteria $^{23,35}$ or initial reduced ejection fraction $^{36}$ predict larger infarct size and patients with inferior infarction more likely to benefit from lytic therapy, we could not confirm those findings in our patients, most of whom had angioplasty. Until more rigorous selection criteria can be formulated based upon mortality data in prospec- tive randomized trials, the data from the current study suggest that reperfusion therapy in patients with inferior myocardial infarction who present within 3 hours of symptom onset with ST segment elevation in at least two contiguous ECG leads will improve left ventricular function. Additional data are required to determine whether patient survival is also increased.

\section{REFERENCES}

1. Geltman EM, Ehsani AA, Campbell MK, Schechtman K, Roberts R, Sobel BE. The influence of location and extent of myocardial infarction on long-term ventricular dysrhythmia and mortality. Circulation 1979;60:805-14.

2. Thanavaro S, Kleiger RE, Province MA, Hubert JW, Miller JP, Krone RJ, Oliver GC. Effect of infarct location on the in-hospital prognosis of patients with first transmural myocardial infarction. Circulation 1982;66:742-7.

3. Hands ME, Lloyd BL, Robinson JS, de Klerk N, Thompson PL. Prognostic significance of electrocardiographic site of infarction after correction for enzymatic size of infarction. Circulation 1986;73:885-91.

4. Hamby RI, Hoffman I, Hilsenrath J, Aintablian A, Shanies S, Padmanabhan VS. Clinical, hemodynamic and angiographic aspects of inferior and anterior myocardial infarctions in patients with angina pectoris. Am J Cardiol 1974;34:513-9.

5. Reduto LA, Berger HJ, Cohen LS, Gottschalk A, Zaret BL. Sequential radionuclide assessment of left and right ventricular performance after acute transmural myocardial infarction. Ann Intern Med 1978;89:441-7.

6. Rentrop P. Mortality and functional change after intracoronary streptokinase infusion (abstr). Circulation 1982;66 (suppl II):II-335.

7. Sheehan FH, Mathey DG, Schofer J, Hodge HT, Bolson EH. Factors that determine recovery of left ventricular function after thrombolysis in patients with acute myocardial infarction. Circulation 1985;71:1121-8.

8. Sheehan FH, Schoffer J, Mathey DG, Kellet MA, Smith H, Bolson EL, Dodge HT. Measurement of regional wall motion from biplane contrast ventriculograms. A comparison of the 30 degree right anterior oblique and 60 degree left anterior oblique projections in patients with acute myocardial infarction. Circulation 1986;74:796-804.

9. Sandler H, Dodge HT. The use of single-plane angiocardiograms for the calculation of left ventricular volume in man. AM HEART J 1968;75:325-34.

10. Bolson EL, Kliman S, Sheehan FH, Dodge HT. Left ventricular segmental wall motion: A new method using local direction information. IEEE Comput Cardiol 1980;245-8.

11. Sheehan FH, Mathey DG, Schofer J, Krebber HJ, Dodge HT. Effect of interventions in salvaging left ventricular function in acute myocardial infarction: A study of intracoronary streptokinase. Am J Cardiol 1983;52:431-8.

12. Ritchie JL, Davis KB, Williams DL, Caldwell J, Kennedy JW. Global and regional left ventricular function and tomographic radionuclide perfusion: The Western Washington Intracoronary Streptokinase in Myocardial Infarction Trial. Circulation 1984;70:867-75.

13. Stratton JR, Speck SM, Caldwell JH, Stadius ML, Maynard C, Davis KB, Ritchie JL, Kennedy JW. Late effects of intracoronary streptokinase on regional wall motion, ventricular aneurysm and left ventricular thrombus in myocardial infarction: Results from the Western Washington Randomized Trial. J Am Coll Cardiol 1985;5:1023-8

14. Serruys PW, Simoons ML, Suryapranata H, Vermeer F, Wijns W, van der Brand $M$, Bar F, Zwaan C, Krauss XH, Remme WJ, Res J, Verheugt FWA, van Domberg R, Lubsen J, Hugenholtz PG. Preservation of global and regional left 
ventricular function after early thrombolysis in acute myocardial infarction. J Am Coll Cardiol 1986;7:729-42.

15. Rentrop P, Blanke $H$, Karsch $K R$, Rutsch W, Schartl M, Merx W, Dorr R, Mathey D, Kuck K. Changes in left ventricular function after intracoronary streptokinase infusion in clinically evolving myocardial infarction. AM HEART $J$ 1981;102:1188-93.

16. Schwarz F, Schuler G, Kauts H, Hoffman M, Manthey J, Tillman $\mathrm{H}$, Mehmel HC, Kubler W. Intracoronary thrombolysis in acute myocardial infarction: Duration of ischemia as a major determinant of late results after recanalization. Am J Cardiol 1982;50:933-7.

17. Schroder R, Biamino G, von Leitner ER, Linderer T, Bruggeman T, Heitz J, Vohringer H-F, Wegscheider K. Intravenous short-term infusion of streptokinase in acute myocardial infarction. Circulation 1983;67:536-48.

18. Spann JF, Sherry S, Carrabello BA, Denenberg BS, Mann RH, McCann WD, Gault JH, Gentzler RD, Belber AD, Maurer AD, Cooper EM. Coronary thrombolysis by intravenous streptokinase in acute myocardial infarction: Acute and follow-up studies. Am J Cardiol 1984;53:655-61.

19. Stack RS, Phillips, HR, Grierson DS, Behar VS, Kong Y, Peter RH, Swain JL, Greenfield JC. Functional improvement of jeopardized myocardium following intracoronary streptokinase infusion in acute myocardial infarction. J Clin Invest 1983;72:84-95.

20. O'Neill WW, Timmis GC, Bourdillon PD, Lai $P$, Ganghadarhan V, Walton J, Ramos R, Laufer N, Gordon S, Shork MA, Pitt B. A prospective randomized clinical trial of intracoronary streptokinase versus coronary angioplasty for acute myocardial infarction. N Engl J Med 1986;314:812-8.

21. Mathey DG, Sheehan FH, Schofer H, Dodge HT. Time from onset of symptoms to thrombolytic therapy. A major determinant of myocardial salvage in patients with acute transmural infarction. J Am Coll Cardiol 1985;6:518-25.

22. Simoons ML, Serruys PW, van den Brand M, Res J, Verheugt FWA, Krauss XH, Remme WJ, Bar F, de Zwann C, van der Laarse A, Vermeer F, Lubsen J. Early thrombolysis in acute myocardial infarction: Limitation of infarct size and improved survival. J Am Coll Cardiol 1986;7:717-28.

23. Berland J, Cribier A, Behar P, Letac B. Anterior ST depression in inferior myocardial infarction: Correlation with results of intracoronary thrombolysis. AM HEART J 1986; 111:481-8

24. Harrison DG, Ferguson DW, Collins SM, Skorton DJ, Ericksen EE, Kiochos JM, Marcus ML, White CW. Rethrombosis after reperfusion with streptokinase: Importance of geometry of residual lesions. Circulation 1984;69:991-9.

25. Schroder R, Vohringer H, Linderer T, Biamino G, Bruggemann $T$, von Leiter ER. Follow-up after coronary arterial reperfusion with intravenous streptokinase in relation to residual myocardial infarct artery narrowings. Am J Cardiol 1985;55:313-7.

26. Hartzler GO, Rutherford BD, McConahay DR, Johnson WL,
McCallister BD, Gura GM, Conn RC, Crockett JE. Percutaneous transluminal coronary angioplasty with and without thrombolytic therapy for treatment of acute myocardial infarction. AM HEART J 1983;106:965-73.

27. Yasuno M, Saito Y, Ishida M, Suzuki K, Endo S, Takahashi M. Effects of percutaneous transluminal coronary angioplasty: Intracoronary thrombolysis with urokinase in acute myocardial infarction. Am J Cardiol 1984;53:1217-20.

28. Mathey DG, Rodewald G, Rentrop P, Leitz K, Merx W, Messmer BJ, Rutsch W, Bucherl ES. Intracoronary streptokinase thrombolytic recanalization and subsequent surgical bypass of remaining atherosclerotic stenosis in acute myocardial infaction: Complementary combined approach effecting reduced infarct size, preventing reinfarction, and improving left ventricular function. AM HEART J 1981;102:1194-1201.

29. Fung AY, Lai P, Topol EJ, Bates ER, Bourdillon PDV, Walton JA, Mancini GBJ, Kryski T, Pitt B, O'Neill WW. Value of percutaneous transluminal coronary angioplasty after unsuccessful intravenous streptokinase therapy in acute myocardial infarction. Am J Cardiol 1986;58:686-91.

30. Topol EJ, O'Neill WW, Langburd AB, Walton JA, Bourdillon PDV, Bates ER, Grines CL, Schork MA, Kline E, Pitt B. Randomized, placebo controlled trial of intravenous recombinant tissue-type plasminogen activator and emergency coronary angioplasty in acute myocardial infarction. Circulation 1987;75:420-428.

31. Koren G, Weiss AT, Hasin Y, Appelbaum D, Welber S, Rozenman Y, Lotan C, Mosseri M, Sapoznikov D, Luria MH, Gotsman MS. Prevention of myocardial damage in acute myocardial ischemia by early treatment with intravenous streptokinase. N Engl J Med 1985;313:1384-9.

32. James TN. Anatomy of the crista supraventricularis: Its importance for understanding right ventricular function, right ventricular infarction and related conditions. J Am Coll Cardiol 1985;6:1083-95.

33. Lang TW, Corday E, Gold H, Meerbaum S, Rubin S, Costantini C, Hirose S, Osher J, Rosen W. Consequences of reperfusion after coronary occlusion. Effects on hemodynamic and regional myocardial metabolic function. Am J Cardiol 1974;33:69-81.

34. Gruppo Italiano Per Lo Studio Della Streptochinasi Nell'infarcto Myocardio (GISSI). Effectiveness of intravenous thrombolytic treatment in acute myocardial infarction. Lancet $1986 ; 1: 397-401$.

35. Barr F, Vermeer F, Krauss XH, Res J, Simoons M, de Zwaan $C$, van der Laarse A, Wellens HJJ. The value of the admission electrocardiogram to predict effect of thrombolysis on infarction size (abstr). J Am Coll Cardiol 1986;7:240A.

36. Timmis GC, Westveer DC, Hauser AM, Stewart JR, Gangadharan V, Ramos RG, Gordon S. The influence of infarction site and size on the ventricular response to coronary thrombolysis. Arch Intern Med 1985;145:2188-93. 